\title{
Unmet Need for Family Planning and Experience of Unintended Pregnancy Among Female Sex Workers in Urban Cameroon: Results From a National Cross-Sectional Study
}

\author{
Anna L. Bowring, ${ }^{a, b}$ Sheree Schwartz, ${ }^{a}$ Carrie Lyons, ${ }^{a}$ Amrita Rao, ${ }^{a}$ Oluwasolape Olawore, ${ }^{a}$ \\ Iliassou Mfochive Nijindam, ${ }^{a, c}$ Jimmy Nzau, ${ }^{d}$ Ghislaine Fouda, ${ }^{e}$ Guy H. Fako, ${ }^{c}$ Gnilane Turpin, ${ }^{a}$ Daniel Levitt, ${ }^{f}$

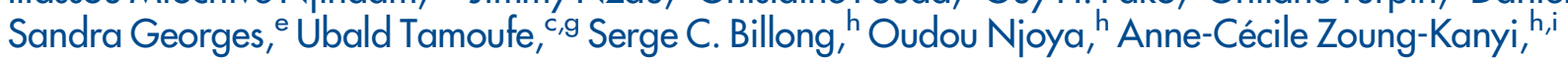 \\ Stefan Baral ${ }^{\mid}$
}

Female sex workers (FSWs) in Cameroon have unmet need for effective contraception, and experience of unintended pregnancy and pregnancy termination is common. Reducing barriers to accessing high-quality, voluntary family planning services in FSW-focused community services is a key strategy to promote clientcentered care, promote informed choice, reduce unintended pregnancies, and improve quality of life for FSWs.

Résumé en français à la fin de l'article.

\section{ABSTRACT}

Background: Female sex workers (FSWs) in Cameroon commonly have unmet need for contraception posing a high risk of unintended pregnancy. Unintended pregnancy leads to a range of outcomes, and due to legal restrictions, FSWs often seek unsafe abortions. Aside from the high burden of HIV, little is known about the broader sexual and reproductive health of FSWs in Cameroon.

Methods: From December 2015 to October 2016, we recruited FSWs aged $\geq 18$ years through respondent-driven sampling across 5 Cameroonian cities. Cross-sectional data were collected through a behavioral questionnaire. Modified-robust Poisson regression was used to approximate adjusted prevalence ratios (aPR) for TOP and current use of effective nonbarrier contraception.

Results: Among 2,255 FSWs (median age 28 years), 57.6\% reported history of unintended pregnancy and 40.0\% reported prior TOP. In multivariable analysis, TOP history was associated with current nonbarrier contraceptive use (aPR=1.23, 95\% confidence interval $[\mathrm{Cl}]=$ 1.07, 1.42); ever using emergency contraception ( $\mathrm{aPR}=1.34,95 \% \mathrm{Cl}=1.17,1.55$ ); $>60$ clients in the past month (aPR=1.29, 95\% $\mathrm{Cl}=$ $1.07,1.54)$ compared to $\leq 30$; inconsistent condom use with clients ( $\mathrm{aPR}=1.17,95 \% \mathrm{Cl}=1.00$, 1.37); ever experiencing physical violence ( $\mathrm{aPR}=1.24,95 \% \mathrm{Cl}=1.09,1.42$ ); and older age. Most (76.5\%) women used male condoms for contraception, but only $33.2 \%$ reported consistent condom use with all partners. Overall, $26.4 \%$ of women reported currently using a nonbarrier contraceptive method, and $6.2 \%$ reported using a long-acting method. Previous TOP ( $\mathrm{aPR}=1.41,95 \% \mathrm{Cl}=1.16,1.72$ ) and ever using emergency contraception ( $\mathrm{aPR}=2.70,95 \% \mathrm{Cl}=2.23,3.26$ ) were associated with higher nonbarrier contraceptive use. Recent receipt of $\mathrm{HIV}$ information ( $\mathrm{aPR}=0.72,95 \% \mathrm{Cl}=0.59,0.89$ ) and membership in an FSW community-based organization ( $\mathrm{aPR}=0.73,95 \% \mathrm{Cl}=0.57,0.92$ ) were associated with lower use nonbarrier contraceptive use.

Conclusions: Experience of unintended pregnancies and TOP is common among FSWs in Cameroon. Given the low use of nonbarrier contraceptive methods and inconsistent condom use, FSWs are at risk of repeat unintended pregnancies. Improved integration of client-centered, voluntary

a Department of Epidemiology, Johns Hopkins Bloomberg School of Public Health, Baltimore, MD, USA.

${ }^{\mathrm{b}}$ Burnet Institute, Melbourne, Australia.

'Metabiota, Yaounde, Cameroon.

${ }^{d}$ CARE SRHR Global Team, Atlanta, GA, USA.

'CARE Cameroon, Yaounde, Cameroon.

${ }^{\dagger}$ CARE USA, New York, NY, USA.

g Johns Hopkins Cameroon Program, Yaounde, Cameroon.

${ }^{h}$ Faculty of Medicine and Biomedical Sciences, University of Yaoundé l, Yaounde, Cameroon.

'Division of Operations Research, Ministry of Health, Yaounde, Cameroon.

Correspondence to Anna Bowring (abowrin $1 @$ jhu.edu). family planning within community-led HIV services may better support the sexual and reproductive health and human rights of FSWs consistent with the United Nations Declaration of Human Rights.

\section{BACKGROUND}

Gemale sex workers (FSWs) have a disproportionate burden of HIV infection and experience systematic barriers to accessing existing HIV prevention and treatment services. ${ }^{1}$ Based on 9 studies conducted during 2011-2016, HIV prevalence among women who sell sex ranged from $11 \%$ to $24 \%$ across western and central 
Africa and was more than $60 \%$ across southern Africa. ${ }^{2}$ Specific guidelines for HIV interventions among FSWs have shaped programs targeting HIV prevention, testing, and treatment. However, less attention has been given to FSWs' other comprehensive sexual and reproductive health services, including voluntary family planning.

FSWs may consider pregnancy prevention a more influential motivator for condom use than HIV prevention. ${ }^{3}$ Previous work has demonstrated that unintended pregnancy is a high-priority issue for FSWs, with unintended pregnancy incidence of 27 per 100 person-years among FSWs in lowand middle-income settings without presence of a sexual and reproductive health intervention. ${ }^{4}$ One potential outcome of unintended pregnancy is termination. Among FSWs, experience of termination of pregnancy (TOP) is widespread in global estimates and often higher than national estimates among all women. ${ }^{5}$ In many countries where FSWs are most affected by unintended pregnancy, abortion policy is generally restrictive, ${ }^{6}$ which can lead to women seeking unsafe abortions. Across sub-Saharan Africa specifically, it is estimated that unsafe abortions contribute to at least $10 \%$ of maternal deaths. ${ }^{6-8}$ In addition, unintended pregnancy leading to live births can have financial implications that may perpetuate vulnerability and HIV risks related to sex work. ${ }^{9,10}$

Male and female condoms remain important means of preventing unintended pregnancy and HIV and STIs among FSWs in 2019. ${ }^{11}$ However, extensive social and structural factors affect both condom use and condom failure among FSWs. ${ }^{12-15}$ These factors include punitive laws and policies, local policing practices, economic insecurity, intersecting stigmas, physical and sexual violence, and drug and alcohol use during sex work. ${ }^{16}$ Even in settings with high levels of consistent condom use with paying partners, condom use between FSWs and their nonpaying or emotional partners is low due to interpersonal barriers to condom use. ${ }^{17,18}$ Previous studies have demonstrated associations between having regular, emotional partners and unintended pregnancy or abortion. ${ }^{19,20}$

In light of the reduced effectiveness of condoms with typical use as opposed to perfect use, $^{21,22}$ especially in the context of violence, ${ }^{16}$ and differences in condom use with clients and nonpaying partners, dual-method contraceptive use-condoms combined with an effective nonbarrier method-for both HIV/STI and pregnancy prevention is recommended for key cisgender women populations. $^{23}$ However, widespread studies have shown that FSWs across several lowand middle-income countries have significant unmet need for effective contraception and voluntary family planning services. ${ }^{5,24}$ The current use of modern nonbarrier methods among FSWs is estimated to be below $40 \%$ in numerous settings across sub-Saharan Africa, ${ }^{25-27}$ and FSWs report most often using injectables or oral contraceptive pills. ${ }^{14,26,28,29}$ Although these are both effective methods with perfect use, ${ }^{21}$ they are userdependent, are prone to misuse due to delays in renewal or well-documented issues with daily adherence, respectively, ${ }^{28}$ and often have high discontinuation of use due to side effects and barriers to accessing family planning services. ${ }^{30-32}$ Long-acting reversible contraceptives (LARCs), which include intrauterine devices (IUDs) and implants, are globally recommended for reducing unintended pregnancy due to high effectiveness, continuation rates, and higher tolerability compared to other nonbarrier methods, ${ }^{31}$ but availability and utilization of LARCs remain low among FSWs in much of sub-Saharan Africa. ${ }^{4,33}$

Women in Cameroon most commonly use short-acting and user-dependent contraceptive methods. In 2015, among a household survey of women in urban Yaoundé using any contraceptive method, only $8 \%$ were using LARCs and an additional 5\% reported using an oral contraceptive pill. ${ }^{34}$ Perceived efficacy and easy accessibility were the 2 main considerations for contraceptive choice, and only half of women were aware of LARCs. In Cameroon, LARCs are intended to be available through hospitals and selected clinics that provide family planning and reproductive health services. ${ }^{34,35}$ However, a recent evaluation indicates that stock-outs prevail, with $70 \%-80 \%$ of facilities reporting stock-outs of each offered LARC method on the day of assessment. ${ }^{36}$ The unmet need for contraception results in high numbers of unintended pregnancies. ${ }^{36}$

Cameroon's abortion policy has been described as restrictive: legally permitted only in cases of rape, incest, or to preserve a woman's physical or mental health, and even then, it can be difficult to obtain legal standing for abortion. ${ }^{37}$ Nonetheless, experiences of abortion are common, with estimates ranging from $20 \%-35 \%$ prevalence among women. ${ }^{38-40}$ Due to legal and regulatory restrictions, abortions are often unsafe. Notably, unsafe abortions have been demonstrated to account for one-quarter of registered maternal deaths in Cameroon. ${ }^{4,42}$ Although generalizable data are limited, abortions have been reported in both home and clinical settings and are most commonly 
provided by nurses, general practitioners, a friend, or through self-induction. The most commonly reported procedures are dilatation and curettage, manual vacuum aspiration, or misoprostal. ${ }^{43}$ There is no standard practice for postabortion care in Cameroon, but it may include further manual vacuum aspiration, sharp curettage, or misoprostal depending on resource availability. ${ }^{37,44}$ It is not clear whether postabortion care services routinely include family planning counseling and methods. ${ }^{37}$

As of 2016, more than 1 in 4 sex workers in Cameroon are estimated to be living with HIV $^{12}$ compared to around 1 in 20 among all women aged 15-64 years. ${ }^{45}$ Sex work is illegal in Cameroon, and arrests as well as police violence, raids, and extortion have been commonly reported. ${ }^{46,47}$ Earlier work has demonstrated that physical and sexual violence as well as depression are prevalent among FSWs in Cameroon and associated with condom nonuse, being offered more money for condomless sex, and condom failure. ${ }^{46,48}$ These circumstances may similarly affect risk of unintended pregnancy. However, there are limited studies evaluating unintended pregnancy, pregnancy outcomes, or related consequences with the majority of studies focused on HIV risks. In response, these analyses aim to fill a gap in knowledge of reproductive health among FSWs in Cameroon by characterizing the prevalence of unintended pregnancy, TOP, and contraceptive use.

\section{These analyses aim to fill a gap in knowledge of reproductive health among FSWs in Cameroon.}

\section{Study Overview and Population}

This is a secondary analysis of data collected through a cross-sectional respondent-driven sampling (RDS) study in 5 cities of Cameroon:

\section{Study Recruitment and Procedures}

Methods have been reported in more detail previously. ${ }^{12,50}$ Briefly, 6 FSWs were purposively selected as "seeds" based on their peer networks. Seeds and subsequent participants were provided with referral coupons to recruit up to 3 other FSWs from their social network for participation. Sampling continued until recruitment across cities reached the desired sample size (Bamenda: 340, Bertoua: 301, Douala: 460, Kribi: 578, Yaoundé: 571). Sample size calculations were based on the estimated HIV prevalence by region and included a design effect of 2, alpha of 0.01 , and were intended to measure HIV prevalence with a precision of $\pm 3 \%$.

Trained interviewers assessed participant eligibility, obtained informed verbal consent, and administered a 45-60-minute questionnaire on individual, community, network, and structurallevel HIV risks; sexual and reproductive health; and service engagement. Questionnaires and biological data were linked by a confidential unique identifying code, and data were nonidentifiable. Women diagnosed with HIV were supported for linkage to treatment; others were linked to community-based HIV prevention and support services. All participants were reimbursed 2,000 FCFA (US\$4) and received an additional 1,000 FCFA (US\$2) for each successful recruit.

Ethical approval and administrative clearance were obtained from the Cameroonian National Research Ethics Committee (reference 2015/05/591/ CE/CNERSH/SP and 2016/06/782/CE/CNERSH/SP) and Ministry of Public Health (reference 631 2315), respectively. Bamenda, Bertoua, Douala, Kribi, and Yaoundé. These represent the 2 largest cities and cities with high absolute and relative population of sex workers. ${ }^{49}$ This study was conducted from December 2015 to October 2016 as a baseline assessment to inform service provision models for the Continuum of prevention, care, and treatment of HIV/AIDS with Most at-risk Populations (CHAMP) program, implemented by an alliance of community-based organizations (CBOs) and led by the nongovernmental organization CARE.

Women were eligible to participate if they were assigned the female sex at birth, reported sex work as their principal source of income in the previous year, were 18 years or older, spoke French or English, and had resided in the city of recruitment for at least 3 months before recruitment.

\section{Outcomes}

The 2 primary outcomes of interest were lifetime experience of TOP and current use of a nonbarrier contraceptive. Given the complexity of measuring unintended pregnancy and bias associated with retrospective reporting of pregnancy intentions, ${ }^{51}$ TOPs was used as an indirect measure of unintended pregnancy as well as an indicator of potential risk to women's health due to unsafe TOP. ${ }^{8}$ Respondents were asked the number of lifetime pregnancies experienced followed by whether they had ever experienced the following outcomes: live birth, stillbirth, miscarriage, or voluntary termination. Participants were also asked to select all methods currently being used to prevent pregnancy. Nonbarrier contraceptive use considIUD, injectable method, implant, or female ered current use of an oral contraceptive pill, 
sterilization. Secondary outcomes considered were unintended pregnancy, defined as ever having a self-reported an unplanned or unwanted pregnancy and LARC use. Unintended pregnancy was defined as a pregnancy that was unplanned or unwanted. LARC use included current use of a contraceptive implant or IUD.

\section{Covariates of Interest}

The association of multiple covariates with TOP and nonbarrier contraception were considered. Covariates related to service access included previous HIV testing, receipt of information on HIV in the previous 6 months, and member of a CBO working with FSWs.

HIV status was categorized as HIV-negative, HIV-positive previously diagnosed, HIV-positive newly diagnosed, and indeterminate based on serological testing and self-reported HIV status.

Covariates related to other contraceptive use and sexual behavior included ever using emergency contraception, number of clients in the past month, condom use with clients, condom use with regular nonpaying partners, number of regular nonpaying partners in the past year, number of times experienced condom failure in the past year, and whether engaged in sex work during last pregnancy. Consistency of condom use was assessed among participants reporting at least 1 of given partner type on an average week and was assessed separately for regular and casual paying and nonpaying partners. Condom use was defined as consistent if they always reported using condoms during vaginal and anal sex with the given partner type and inconsistent if they reported using condoms less than always. In regression analysis, categorization of condom use with clients (regular and casual nonpaying partners combined) also included not having vaginal or anal sex with clients. In addition, future pregnancy intentions were considered, defined as intending to have children in the future (yes, no, does not know).

Covariates related to structural determinants of health included ever experiencing physical violence or assault, ever being forced to have sex, and experience of health-related stigma. Healthrelated stigma included reporting any of the following in relation to involvement in sex work: ever being afraid of seeking health services, avoidance of health services, mistreatment in a health center, heard health providers gossip, denied health services, or forced to have an HIV test.

\section{Analytical Approach}

Data were combined from 5 independent study sites. Primary outcomes are presented as both crude and RDS-adjusted proportions, the latter were calculated by study site and averaged to estimate overall RDS-adjusted proportion.

On account of primary outcomes being common, modified Poisson regression with robust variance was used to approximate prevalence ratios (PR) for each primary outcome. ${ }^{52,53}$ Models were corrected for RDS-weighting and clustering by seed. Firstly, bivariate associations were assessed for variables with theoretical association to the given outcomes. A multivariable model was developed for each primary outcome with variables with a $P$ value $<.1$ in bivariate association. Any regular nonpaying sex partner(s) in the past year and consistent condom use with clients were included $a$ priori in both models, and age group was included $a$ priori when modelling associations with history of TOP. To prevent collinearity between HIV testing history and previous HIV diagnosis, only HIV status was considered in multivariable models.

Site-specific RDS sampling weights were computed using the Gile's SS estimator, which generates weight by estimating the probability of being included in the study using self-reported network size, using RDS Analyst (version 0.42, Los Angeles, CA). All other analyses were conducted using Stata version 14 (StataCorp, College Station, TX). Unless indicated, missing data were omitted from analyses.

\section{RESULTS}

In total, 2,255 FSWs were recruited, age range 18-70 years (median age 28 years, interquartile range [IQR] 23-36) (Table 1). The median age of first sex in exchange for money or goods was 22 years (IQR 12-50). The majority of women $(77.0 \%, 1,735 / 2,254)$ were never married but reported at least 1 regular nonpaying partner in the previous year $(72.8 \%, 1,638 / 2,252)$.

\section{Reproductive Experience}

Overall, 91.5\% (2,058/2,250) of women reported ever being pregnant, and 57.6\% $(1,294 / 2,248)$ of women reported ever having an unintended pregnancy (Table 2). Most women (83.9\%, 1,892/ $2,255)$ reported having living biological children.

Among women with any pregnancy experience, $93.1 \%(1,915 / 2,058)$ had any live births, and $32.3 \%(657 / 2,035)$ of women reported any births since beginning to sell sex. At last pregnancy 
TABLE 1. Sociodemographic Characteristics of Female Sex Workers in 5 Cities, Cameroon

\begin{tabular}{|c|c|c|}
\hline & $N^{a}$ & $\mathrm{n}(\%)$ \\
\hline \multicolumn{3}{|l|}{ Age group, years } \\
\hline $18-24$ & 2,255 & $724(32.1)$ \\
\hline $25-34$ & 2,255 & $890(39.5)$ \\
\hline $35+$ & 2,255 & $641(28.4)$ \\
\hline \multicolumn{3}{|l|}{ Education level } \\
\hline Primary school or less & 2,254 & $702(31.1)$ \\
\hline Any secondary education or higher & 2,254 & $1,552(68.9)$ \\
\hline \multicolumn{3}{|l|}{ Monthly income ${ }^{b}$} \\
\hline$<50000$ XAF & 2,247 & $663(29.5)$ \\
\hline$>=50,000 \mathrm{XAF}$ & 2,247 & $1,584(70.5)$ \\
\hline \multicolumn{3}{|c|}{ Age first sold sex for money or goods, years } \\
\hline$<18$ & 2,234 & $297(13.3)$ \\
\hline $18-24$ & 2,234 & $1,038(46.5)$ \\
\hline $25+$ & 2,234 & $899(40.2)$ \\
\hline \multicolumn{3}{|l|}{ Number of clients in past month } \\
\hline $0-10$ & 2,255 & $681(30.2)$ \\
\hline $11-30$ & 2,255 & $518(23.0)$ \\
\hline $31-50$ & 2,255 & $238(10.6)$ \\
\hline $51+$ & 2,255 & $723(32.1)$ \\
\hline Unknown & 2,255 & $95(4.2)$ \\
\hline \multicolumn{3}{|l|}{ Marital status } \\
\hline Never married & 2,254 & $1,735(77.0)$ \\
\hline Married & 2,254 & $22(1.0)$ \\
\hline Stable partner & 2,254 & $233(10.3)$ \\
\hline Separated/divorced/widowed & 2,254 & $264(11.7)$ \\
\hline \multicolumn{3}{|c|}{ Number of regular nonpaying partners in past year } \\
\hline None & 2,252 & $614(27.3)$ \\
\hline One & 2,252 & $1,222(54.3)$ \\
\hline $2+$ & 2,252 & $416(18.5)$ \\
\hline
\end{tabular}

$34.2 \%(650 / 1,903)$ of women concurrently engaged in sex work.

Overall, $64.4 \%(1,452 / 2,255)$ women intended to become pregnant in the future. The most common contraceptive methods reported being currently used were male condoms $(76.5 \%)$, female condoms $(30.9 \%)$, and the rhythm method $(22.7 \%)$; more than 1 response was permissible.
Based on lifetime recall, $15.8 \%(355 / 2,255)$ of women reported ever using emergency contra-ception. Among these women, the median times of emergency contraception use was 7 (IQR 2-34).

\section{TOP Experience}

Among all women, 40.0\% $(902 / 2,250)$ reported a TOP (RDS-adj 39.8\%, [35.1\%, 44.7\%]) (Table 3). 
TABLE 2. Reproductive Experience and Contraceptive Use of Female Sex Workers in 5 Cities, Cameroon

\begin{tabular}{|c|c|c|}
\hline & $\mathbf{N}$ & n (\%) \\
\hline \multicolumn{3}{|l|}{ Number of lifetime pregnancies } \\
\hline 0 & 2,250 & $192(8.5)$ \\
\hline $1-2$ & 2,250 & $800(35.6)$ \\
\hline $3-4$ & 2,250 & $634(28.2)$ \\
\hline $5+$ & 2,250 & $624(27.7)$ \\
\hline Ever had an unintended pregnancy & 2,248 & $1,294(57.6)$ \\
\hline \multicolumn{3}{|l|}{ Number of living biological children } \\
\hline 0 & 2,255 & $363(16.1)$ \\
\hline 1 & 2,255 & $624(27.7)$ \\
\hline 2 & 2,255 & $587(26.0)$ \\
\hline $3+$ & 2,255 & $681(30.2)$ \\
\hline \multicolumn{3}{|l|}{ Among FSWs ever pregnant: } \\
\hline Any live births & 2,058 & $1,915(93.1)$ \\
\hline Any still births & 2,058 & $164(8.0)$ \\
\hline Any miscarriage & 2,058 & $447(21.7)$ \\
\hline Any termination of pregnancy & 2,058 & $902(43.8)$ \\
\hline Sought antenatal care at last pregnancy & 2,057 & $1,712(83.2)$ \\
\hline \multicolumn{3}{|l|}{ Among FSWs with any live births $(\mathrm{N}=1915)$} \\
\hline \multicolumn{3}{|l|}{ FSW age at first birth } \\
\hline$<18$ years & 1,891 & $1,286(68.0)$ \\
\hline $18+$ years & 1,891 & $605(32.0)$ \\
\hline \multicolumn{3}{|l|}{ Births while FSW } \\
\hline 0 & 1,892 & $1,235(65.3)$ \\
\hline 1 & 1,892 & $405(21.4)$ \\
\hline $2+$ & 1,892 & $252(13.3)$ \\
\hline Engaged in sex work during last pregnancy & 1,903 & $650(34.2)$ \\
\hline \multicolumn{3}{|l|}{ Time to return to sex work during last pregnancy } \\
\hline 0-3 months & 634 & $311(49.0)$ \\
\hline $4-6$ months & 634 & $143(22.6)$ \\
\hline 7-9 months & 634 & $66(10.4)$ \\
\hline $10-12$ months & 634 & $78(12.3)$ \\
\hline$>1$ year & 634 & $36(5.7)$ \\
\hline \multicolumn{3}{|l|}{ Future pregnancy intentions } \\
\hline No & 2,255 & $761(33.7)$ \\
\hline Yes & 2,255 & $1452(64.4)$ \\
\hline Don't know & 2,255 & $42(1.9)$ \\
\hline
\end{tabular}


TABLE 2. Continued

\begin{tabular}{|c|c|c|}
\hline & $\mathbf{N}$ & n (\%) \\
\hline \multicolumn{3}{|l|}{ Consistent condom use ${ }^{a}$ : } \\
\hline With clients & 2,237 & $1734(77.5)$ \\
\hline With regular nonpaying partners & 1,565 & $306(19.6)$ \\
\hline With all partners ${ }^{b}$ & 2,251 & $747(33.2)$ \\
\hline \multicolumn{3}{|l|}{ Current contraceptive use ${ }^{c}$ : } \\
\hline Male condom & 2,255 & $1,724(76.5)$ \\
\hline Female condom & 2,255 & $697(30.9)$ \\
\hline Oral contraceptive pill & 2,255 & $284(12.6)$ \\
\hline Injectable & 2,255 & $205(9.1)$ \\
\hline Intrauterine device & 2,255 & $52(2.3)$ \\
\hline Implant & 2,255 & $93(4.1)$ \\
\hline Diaphragm & 2,255 & $2(0.1)$ \\
\hline Rhythm method & 2,255 & $511(22.7)$ \\
\hline Withdrawal method & 2,255 & $224(9.9)$ \\
\hline Female sterilization & 2,255 & $32(1.4)$ \\
\hline Other $^{d}$ & 2,255 & $62(2.7)$ \\
\hline Ever used emergency contraception & 2,255 & $355(15.8)$ \\
\hline \multicolumn{3}{|c|}{$\begin{array}{l}\text { Abbreviations: FSW, female sex worker. } \\
\text { a Reported among individuals reporting at least } 1 \text { of given partner type in an average week and refers to condom use during vaginal } \\
\text { and anal sex. } \\
\text { b Incudes regular and casual paying partners and regular and casual nonpaying partners. } \\
\text { c Respondents could select more than one contraceptive and percentages do not add up to } 100 \text {. } \\
\left.\left.{ }^{d} \text { Includes drinking whisky ( } n=22\right) \text {, traditional medicine }(n=8) \text {, salted water ( } n=7\right) \text {, paracetamol/aspirin/quinine (n=5), menopause } \\
(n=5) \text {, Nescafé (n=3). }\end{array}$} \\
\hline
\end{tabular}

TOP was higher among women living with HIV $(44.3 \%, 243 / 548)$ than those who were not living with HIV (38.8\%, 658/1,695, $P=.027)$.

In multivariable analyses, variables associated with higher prevalence of lifetime TOP were: older age, aged $25-34$ years (aPR $=1.46,95 \%$ confidence interval $[\mathrm{CI}]=1.19,1.79)$ or $\geq 35$ years $(\mathrm{aPR}=1.70,95 \%$ $\mathrm{CI}=1.35,2.13)$ compared to aged 18-24 years; residing in Douala $(\mathrm{aPR}=1.21,95 \% \mathrm{CI}=1.04,1.42)$ or Bamenda $(\mathrm{aPR}=1.26,95 \% \mathrm{CI}=1.04,1.53)$ compared to Yaoundé; currently using a nonbarrier contraceptive $(\mathrm{aPR}=1.23,95 \% \mathrm{CI}=1.07,1.42)$; ever using emergency contraception (aPR 1.34, 95\% CI= $1.17,1.55)$; >60 clients in the past month (aPR $1.29,95 \% \mathrm{CI}=1.07,1.54$ ) compared to 30 or less; reporting inconsistent condom use with clients (aPR=1.17, 95\% CI=1.00, 1.37); and ever experiencing physical violence or assault $(\mathrm{aPR}=1.24$, 95\% CI=1.09, 1.42) (Table 4).

\section{Condom Use}

Overall, $77.5 \%(1,734 / 2,237)$ of women reported consistent condom use with clients. In addition to paying clients, FSWs reported nonpaying regular $(72.7 \%, 1,638 / 2,252)$ and casual $(22.6 \%, 509 / 2,252)$ partners in the previous year. Considering all sex partners, 33.2\% (747/ $2,251)$ of women reported consistent condom use (Table 2).

In the past year, $36.7 \%(806 / 2,198)$ of participants reported experiencing condom failure $1-4$ times and a further $23.5 \%(516 / 2,198) 5$ or more times.

\section{Nonbarrier Contraceptive Use}

Overall, 6.2\% (140/2,255) women reported currently using any LARC, and 26.4\% (596/2,255 RDS-adj $27.1 \% \quad[22.9 \%, 31.7 \%])$ reported 
TABLE 3. Crude and RDS-Adjusted Prevalence of TOP and Current Nonbarrier Contraceptive Method Use by Study Site and Overall

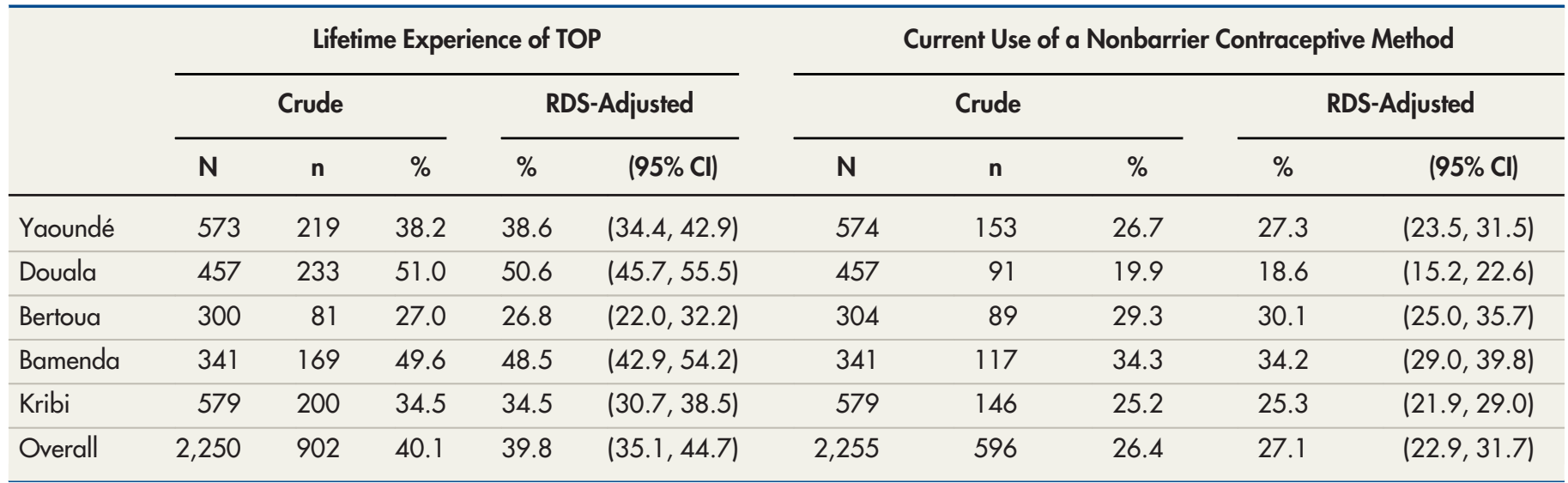

Abbreviations: $\mathrm{Cl}$, confidence interval; RDS, respondent-driven sampling; TOP, termination of pregnancy.

currently using any nonbarrier contraceptive method (Table 3). Nonbarrier contraception was trending higher among women not living with HIV $(27.6 \%, 469 / 1,698)$ compared to women living with HIV $(22.9 \%, 126 / 550, \quad P=.072)$. Approximately half $(51.2 \%, 1,152 / 2,251)$ of women reported either nonbarrier contraceptive use or consistent condom use with all partners.

In multivariable analyses, variables associated with higher use of nonbarrier contraception were: previous TOP $(\mathrm{aPR}=1.41$, 95\% CI $=1.16$, 1.72) and ever using emergency contraception $(\mathrm{aPR}=2.70,95 \% \mathrm{CI}=2.23,3.26)$. Variables associated with lower use of nonbarrier contraception were: receipt of HIV information in the previous 6 months $(\mathrm{aPR}=0.72,95 \% \mathrm{CI}=0.59,0.89)$ and membership in an FSW-CBO (aPR $=0.73$, 95\% $\mathrm{CI}=0.57,0.92)$ (Table 5).

\section{Experience of Violence}

Overall, 24.8\% (559/2,251) of participants had experienced physical violence, and 32.6\% (735/ 2,253 ) had ever been forced to have sex. Physical violence was most commonly perpetrated by clients $(67.6 \%, 378 / 559)$, a uniformed officer $(25.4 \% ; 142 / 559)$, a boyfriend or husband $(17.4 \%, 97 / 559)$, or another FSW $(22.2 \%, 124 /$ $559)$. Sexual violence was most commonly perpetrated by clients $(33.3 \%, 245 / 735)$, a stranger $(29.3 \%, 215 / 735)$, or a boyfriend or husband $(17.0 \%, 125 / 735)$.

\section{DISCUSSION}

FSWs across 5 cities in Cameroon experienced a high burden of unintended pregnancy and TOP.
Given the history of inconsistent or no condom use, nonbarrier contraceptive use is highly indicated to prevent unintended pregnancies and associated health consequences, but coverage among FSWs was low. These results remind us that the health needs of FSWs in Cameroon extend beyond HIV and underscore the importance of removing structural barriers as integral to optimizing coverage of health care services. The evidence suggests that community-based and FSW-focused services in Cameroon do not currently meet these broader needs. Comprehensive services, including access to client-centered, voluntary family planning counseling and services, are needed to effectively address FSWs' fertility and reproductive health needs. ${ }^{54}$

Compared to other studies of FSWs, experience of TOP was similar or higher than observed across Southern Africa. ${ }^{29,55}$ TOP estimates among FSWs were twice as high as those reported among young women in urban areas or women seen in antenatal care (ANC) in other Cameroon-based studies. $^{38,40}$ TOP performed in unsafe settings, even if supported by a health care worker, may lack appropriate counseling and information and miss opportunities to prevent future unintended pregnancy. ${ }^{6,8,56}$ Although this information was not collected here, among women with history of TOP in Cameroon, less than one-third reported currently using a non-barrier contraceptive and nearly one-quarter reported inconsistent condom use with clients. Subsequently, these women are likely at risk of future unintended pregnancies.

Findings from this study suggest that high burden of targeted violence in the context of criminalization experienced by FSWs may increase

\section{Although FSWs have a history of unintended pregnancy and termination of pregnancy coupled with inconsistent condom use, nonbarrier contraceptive use remains low.}

\section{High burden of targeted violence experienced by FSWs may increase vulnerability to TOP.}


TABLE 4. Associations with Experience of TOP Among FSWs in Univariate and Multivariable Poisson Regression Corrected for RDSWeighting and Clustering by Seed, Cameroon

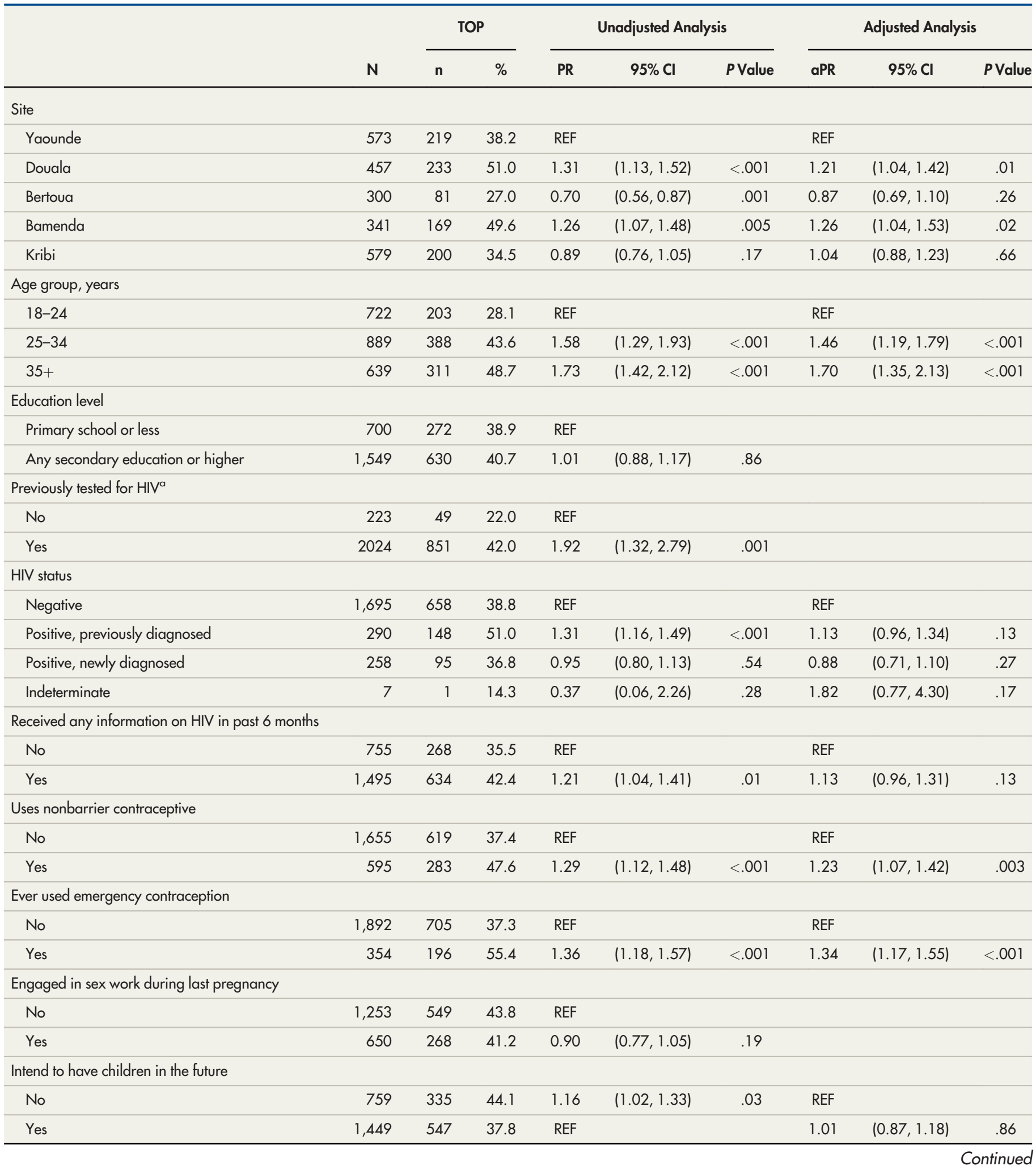


TABLE 4. Continued

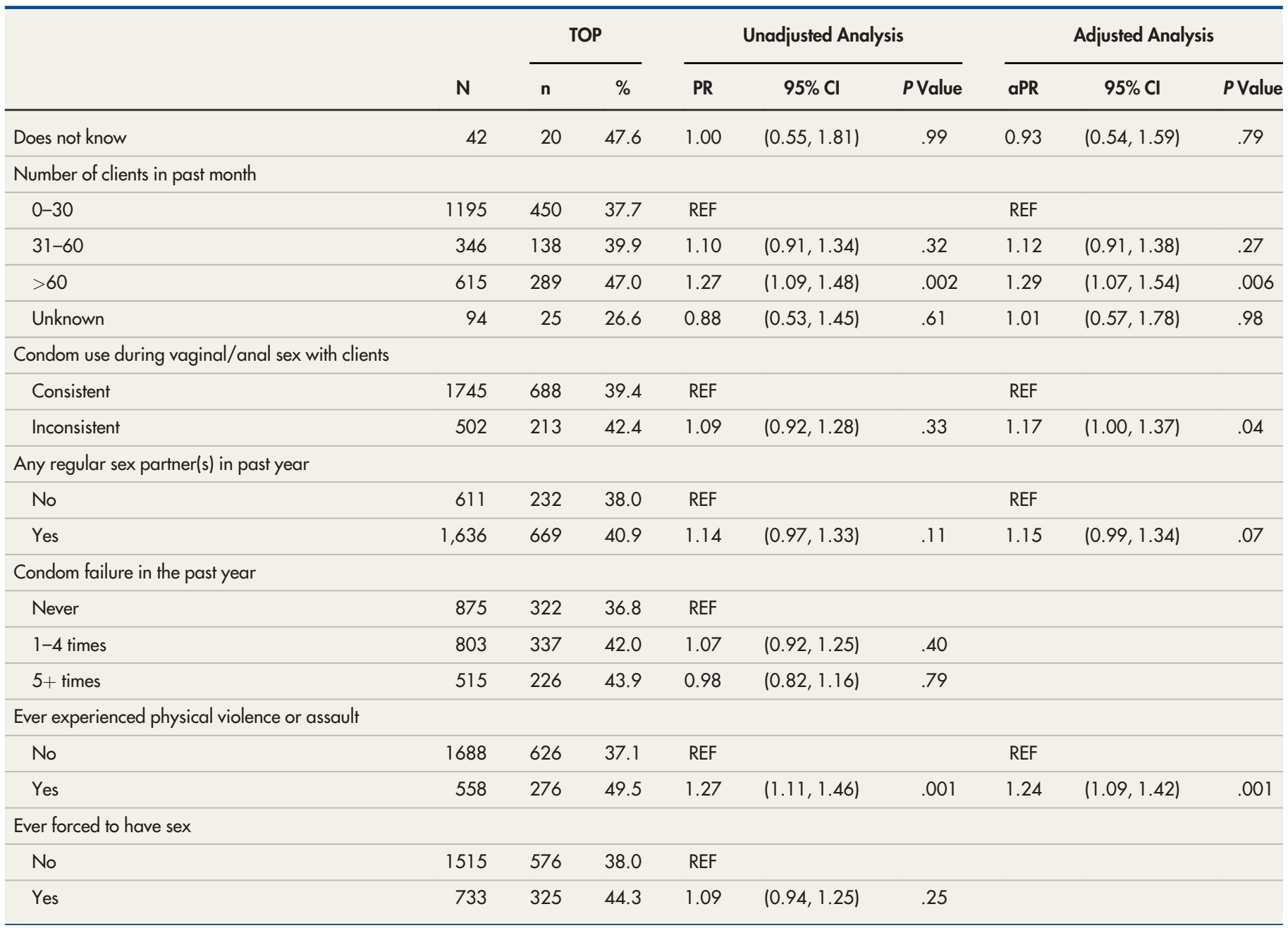

Abbreviations: aPR, adjusted prevalence ratio; Cl, confidence interval; FSW, female sex worker; PR, prevalence ratio; RDS, respondent-driven sampling; TOP, termination of pregnancy.

a Excluded from adjusted analyses due to collinearity with HIV status.

vulnerability to TOP. ${ }^{16}$ Links between violence and unintended pregnancy have also been reported in other settings, ${ }^{57}$ and associations between violence and HIV acquisition among FSWs are well-described. ${ }^{14,16,58}$ The relationships between violence and unintended pregnancy are likely similarly multifaceted. ${ }^{58,59}$ Violence and condom failure are commonly related, ${ }^{15,46}$ and past year condom failure was exceptionally common among this group of FSWs. In addition, it is possible that unintended pregnancy may itself trigger intimate partner violence. ${ }^{60}$ Given that physical violence is not factored into the conditions for legal abortion, FSWs experiencing physical violence leading to or arising from unintended pregnancy may perceive a lack of support to safely consider their options. Including access to emergency contraception and HIV postexposure prophylaxis as part of services for violence prevention and response could prevent unintended pregnancy and HIV acquisition resulting from sexual or physical violence. Programs that encourage social cohesion may help strengthen existing networks for violence coping and prevention mechanisms among FSWs. ${ }^{16,61}$ Uniformed officers have been common perpetrators of violence in this and other settings, ${ }^{16}$ suggesting the utility of training these officers in the public health outcomes of punitive enforcement as well as legal advocacy to overcome policy-level 
TABLE 5. Associations with Nonbarrier Contraceptive Method Use Among FSWs in Univariate and Multivariable Poisson Regression Corrected for RDS-Weighting and Clustering by Seed, Cameroon

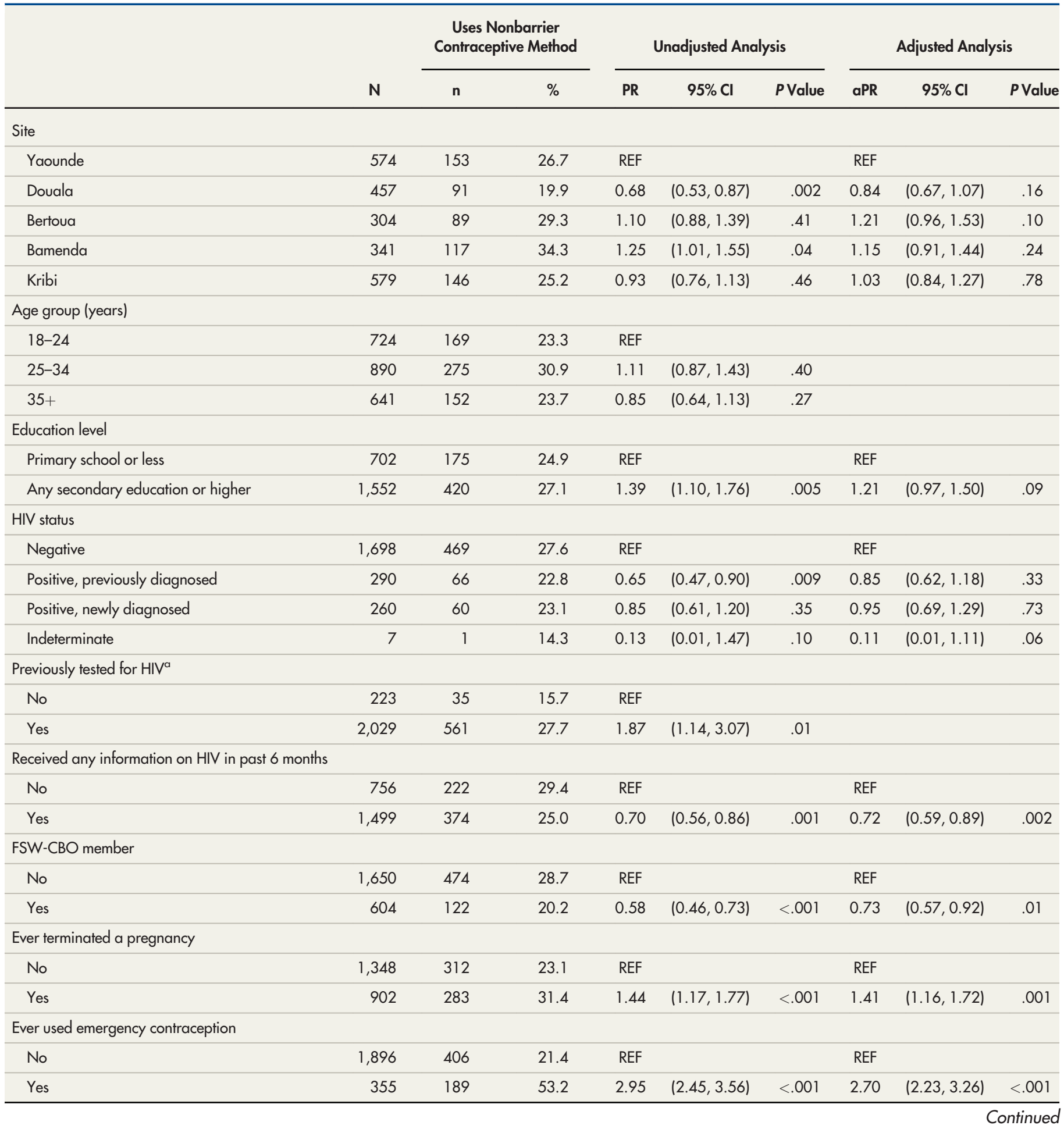


TABLE 5. Continued

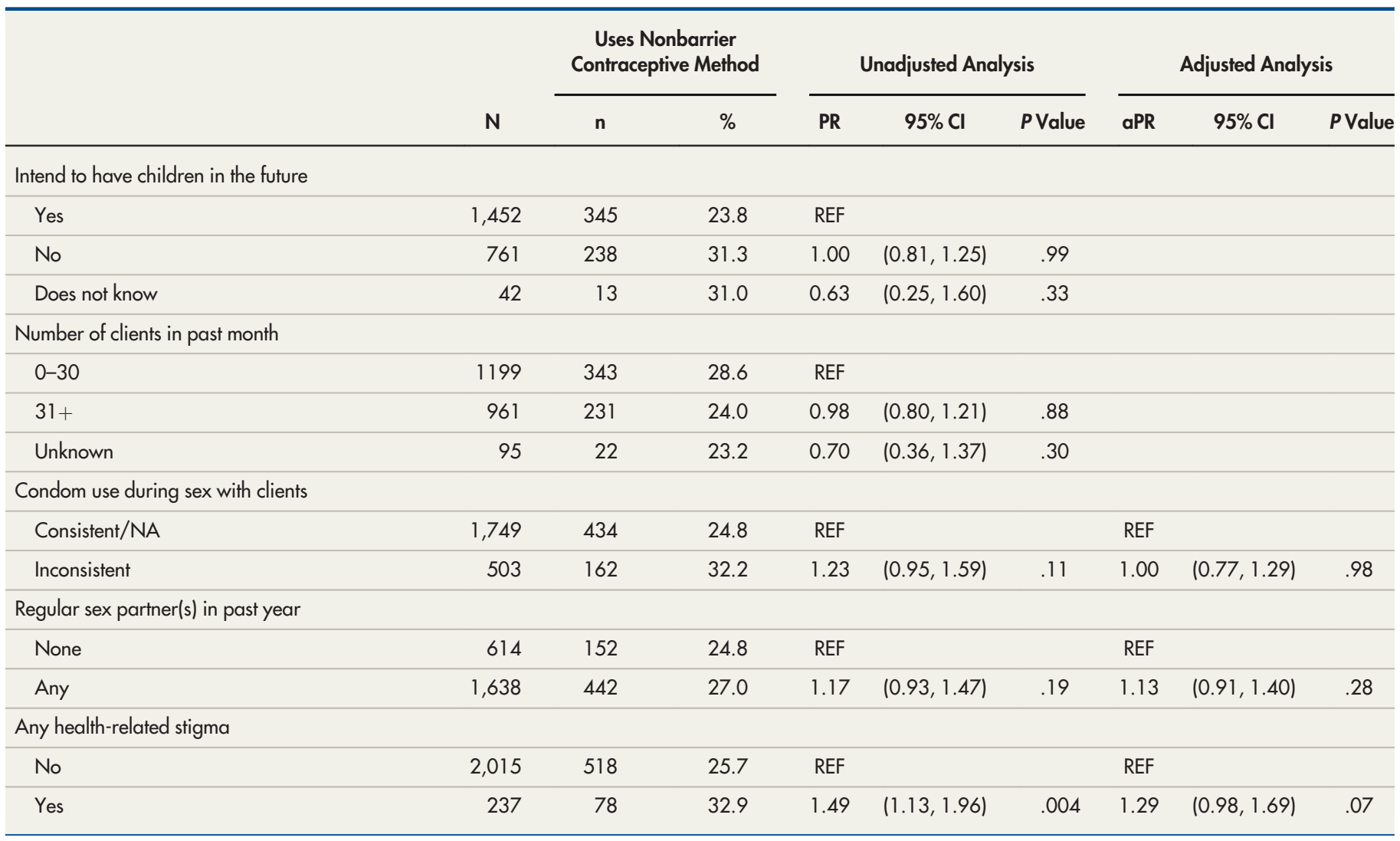

Abbreviations: aPR, adjusted prevalence ratio; CBO, community-based organization; Cl, confidence interval; FSW, female sex worker; NA, not applicable; PR, prevalence ratio; RDS, respondent-driven sampling; TOP, termination of pregnancy.

a Excluded from adjusted analyses due to collinearity with HIV status.

structural determinants in promoting greater protection and access to health and justice for FSWs. ${ }^{47,61}$

Unintended pregnancy is largely preventable through effective nonbarrier contraceptives or consistent and correct condom use. FSWs in Cameroon were generally reliant on condoms for contraception, with limited use of nonbarrier methods and even lower use of more effective LARCs. This finding is consistent with the low use of LARCs in general across Cameroon, ${ }^{34}$ which despite government committment ${ }^{62}$ has not expanded at the same rate as observed in countries across eastern and southern Africa. ${ }^{63}$ We also identified differences in contraceptive access within Cameroon, with relatively higher access in Bamenda despite regional sociopolitical unrest. A similar finding has been previously reported in relation to ANC services in Cameroon and may be due to long-standing investment and resource mobilization in the region where Bamenda is located. ${ }^{64}$

Despite the reliance on condoms, most women did not report consistent condom use, particularly with nonpaying partners. There is substantial evidence from Cameroon and further abroad that pervasive structural factors, such as violence, stigmatization, price premiums for condomless sex, legal status, and policing, as well as social considerations, undermine FSWs agency to negotiate condom use consistently. ${ }^{46,48,65}$ Although current fertility intentions were not known, half of women were susceptible to pregnancy due to inadequate contraceptive use. Access to contraceptive choice and counseling is an essential part of sexual and reproductive health services. ${ }^{54}$ Expanding access to nonbarrier contraceptives and emergency contraception can reduce the risk of unintended pregnancy and related health, social, and economic consequences and provide women greater 


Interventions
targeting the
social and
structural
influences on
condom use are
needed to
promote the
comprehensive
protection of dual-
method use for
HIV and STI
prevention.

Expanding
community-
based, FSW-led
services to include
integrated family
planning, STI, and
HIV service
delivery may be
an effective
strategy to reduce
unintended
pregnancies
among FSWs.

control over the timing and number of their children. ${ }^{66}$

Supplementary interventions targeting the social and structural influences on condom use are still needed to promote the comprehensive protection of dual-method use for HIV and STI prevention. ${ }^{11,16}$ Alternative user-controlled interventions for HIV prevention such as through pre-exposure prophylaxis may also benefit FSWs. ${ }^{11,66}$ Programs implementing single-purpose interventions such as contraception, pre-exposure prophylaxis, and antiretroviral therapy to FSWs can benefit from maintaining a comprehensive view of sexual and reproductive health. For example, proactively considering existing contraceptive mix and accessibility as pre-exposure prophylaxis is scaled up can maximize opportunities to prevent unintended pregnancies and counter potential changes in condom negotiation power or resource allocation. ${ }^{66,67}$ In addition to meeting the broader needs of FSWs, STI education, screening, prevention, and treatment programs can help prevent the potential STIrelated risks associated with IUD use in the context of voluntary family planning services. ${ }^{68}$

With the exception of HIV testing, indicators of HIV service access-in particular FSW-oriented community services-were associated with substantially lower coverage of nonbarrier contraceptives. In comparison, membership in an FSWoriented $\mathrm{CBO}$ was associated with higher recent HIV testing (data not shown). In Cameroon, most community-based facilities serving FSWs currently offer services fairly focused on HIV prevention, testing, and treatment support, with family planning often limited to counseling. ${ }^{69}$ Although these services appear to be an effective way to deliver HIV testing to FSWs, ${ }^{70}$ they may miss opportunities for contraceptive provision. Requiring women to access multiple service points to meet their sexual and reproductive health needs may further disincentivize contraceptive use and act as a structural barrier. ${ }^{71}$ This may be particularly relevant given there are already well-characterized barriers affecting FSWs' access to family planning through public clinics. ${ }^{72,73}$ Further qualitative research to assess personal considerations, barriers, and facilitators of voluntary contraceptive use among FSWs in Cameroon, including emergency contraception, could better inform local family planning delivery strategies and integration of services adapted to the needs and preferences of FSWs. Elsewhere, it has been demonstrated that FSWled mobilization for HIV services through community drop-in centers has been associated with reductions in HIV incidence among FSWs in Tanzania. ${ }^{70}$ Expanding this community empowerment model for integrated family planning, STI, and HIV service delivery may represent an effective strategy to reduce unintended pregnancies and be responsive to critical health care needs.

Although there is growing evidence that integrated HIV and family planning delivery in a single location facilitates contraceptive uptake, ${ }^{71,74,75}$ there are several considerations for implementation within existing community-based HIV services. There is empirical evidence that providing multiple contraceptive options improves uptake. ${ }^{76}$ Elsewhere, making longer-acting methods readily available to FSWs at a drop-in center alongside counseling on methods suited to a woman's needs and current fertility intentions significantly increased demand and uptake of effective contraceptives. ${ }^{75}$ However, the predominance of lower cadres of health care workers and peer outreach workers who often staff community-led FSW services may limit the number of staff with specific training and skills for contraception administration, especially when considering voluntary LARCs. ${ }^{77,78}$ Physical space with adequate privacy and space for an examination table required for LARC administration may also be limited in drop-in centers. ${ }^{78}$ Within the setting of community-based services, means to improve contraception availability and coverage may include task-sharing ${ }^{79}$ and collaborations with services already providing family planning or ANC to offer periodic clinics with outside staff within the community-based settings. Active, facilitated referrals may reduce the number of women falling through the service gap ${ }^{80}$ but may still pose barriers to some women. Lastly, not all FSWs in Cameroon are regularly accessing HIV testing $^{12}$ and the majority were not associated with an FSW-focused CBO at the time of study. A single model of HIV and family planning integration is unlikely to reach all women, and considering alternative points of service access for multipronged, bidirectional approaches to integration and family planning service delivery may optimize coverage. $^{81,82}$

As for many working cisgender women, FSWs are often mothers with ongoing fertility desires. ${ }^{83}$ Consequently, they would benefit from family planning services that are adaptive to changes in fertility intentions and contraceptive needs, including services for safer conception and 
pregnancy. Given pregnancy experience, including a sizeable proportion of pregnancies occurring after women began sex work, FSWs may benefit from greater links between FSW-oriented services and ANC. Approximately one-third of FSWs engaged in sex work during their last pregnancy, with potential for ongoing acquisition risks and resulting vertical transmission, especially if HIV is newly acquired in this period and missed by traditional approaches for preventing vertical transmission. ${ }^{84}$ Although the majority of women had sought ANC at last pregnancy, it is has been documented that FSWs as well as young, unmarried women commonly face stigma in ANC services and subsequently may avoid disclosure, thus limiting access to appropriate services. ${ }^{85-87}$ In our case, we identified associations between health care-related stigma and current use of nonbarrier contraception. Strengthening bidirectional collaborations between FSW-oriented services and ANC may foster more equitable access to quality and respectful family planning and ANC services for FSWs, including women living with HIV.

\section{Limitations}

These findings are subject to several limitations. Indicators related to sexual and reproductive health were asked as part of a broader survey on HIV risk and vulnerability. There was limited space to comprehensively explore domains related to unintended pregnancy and TOP experiences. Because we did not assess current pregnancy intentions, we could not determine the current unmet need for contraception. Pregnancy outcomes were assessed based on lifetime experience rather than specific to each pregnancy, and contraception was assessed in a different timeframe based on current use. TOP was used as an indirect measure of unintended pregnancy due to biases associated with direct, retrospective measurement of unintended pregnancy. ${ }^{51}$ Some discrepancy is expected given that not all unintended pregnancies will result in TOP and TOP may also occur after planned pregnancies. With the exception of HIV status, all indicators were based on self-report and may be subject to social desirability and recall biases. However, despite social desirability biases, reported history of termination was high and reported use of current contraception low. Importantly, data collected were cross-sectional and causality cannot be inferred. Lastly, findings are based on FSWs recruited from 5 urban cities; access to contraception and TOP likely differs among women residing in rural areas, and findings cannot be generalized.

\section{CONCLUSION}

In conclusion, experience with unintended pregnancy is common among FSWs in Cameroon, and women seeking TOP likely face risks associated with unsafe abortion given the restrictive legal environment. The ultimate direct and indirect impacts of TOP on health and mortality cannot be ascertained from these cross-sectional data, and longitudinal follow-up of women is needed to understand sexual and reproductive health outcomes that transcend HIV. The structural drivers of excess violence among FSWs remain a critical barrier to upholding the sexual and reproductive health and human rights of FSWs consistent with the United Nations Declaration of Human Rights. Reliance on condoms alone for preventing both HIV and pregnancy are failing the health needs of FSWs in Cameroon. Although the potential preventive impact of condoms has been substantial and continued promotion is critical, improved access to high-quality family planning counseling and a wider range of contraceptives, including nonbarrier and particularly long-acting contraceptives, is also necessary to improve clientcentered care, promote informed choice, and reduce unintended pregnancies. Ultimately, mitigating structural and facility-level barriers to the coverage of high-quality, voluntary family planning services and method choice in FSW-focused community services represents a key strategy to overcome current barriers to access and move towards optimizing sexual and reproductive health outcomes among FSWs.

\begin{abstract}
Acknowledgments: The authors would like to sincerely thank the study participants for their time and for sharing their experiences and data to advance this research. We also acknowledge and thank all study team members, advisors, and supporting staff from community-based organizations for their valuable contributions to the study. Partners in Continuum of prevention, care, and treatment of HIV/AIDS with Most atrisk Populations project and those involved in the implementation of this study included CARE Cameroon, CARE USA, Johns Hopkins Bloomberg School of Public Health, Metabiota, Moto Action, the National AIDS Control Committee/Comité National de Lutte contre le Sida, Horizons Femmes, Humanity First, Alternatives, Alcondoms, Cameroon Medical Women's Association, Cameroon National Association for Family Welfare, La Direction de la Recherche Operationnelle en Santé, L'Institut Nationale de Statistique, and L'Observatoire National de la Santé Publique du Cameroun. Our great appreciation also goes to the following collaborating health facilities: Yaounde Military Hospital, Biyem-Assi District Hospital, Laquintinie Hospital, Douala Military Hospital, Nylon District Hospital, Centre Médical D'Arrondissement Soboum, Bertoua Regional Hospital, Bamenda Regional Hospital, and Kribi District Hospital. The authors extend their gratitude to the Cameroon government and in particular the Minister of Public Health, the Permanent Secretary of the National AIDS Control Committee, and their collaborators.
\end{abstract}

Funding: This research was generously supported by the U.S. President's Emergency Plan for AIDS Relief (PEPFAR) through the U.S. Agency for International Development (USAID) under the terms of the Continuum of prevention, care, and treatment of HIV/AIDS with Most at-risk Populations project. $A B$ is supported by an Australian National Health 
and Medical Research Council (NHMRC) Early Career Fellowship. SB's and SS's efforts were funded in part by a grant from the National Institute of Nursing Research of the National Institutes of Health (R01NR016650) and the Johns Hopkins University Center for AIDS Research (CFAR). CFAR is an National Institute of Health (NIH)-funded program (P30AI094189) that is supported by the following NIH cofunding and participating institutes and centers: National Institute of Allergy and Infectious Diseases, National Cancer Institute, National Institute of Child and Human Development, National Heart, Lung, and Blood Institute, National Institute on Drug Abuse, National Institute of Mental Health, National Institute on Aging, Fogarty International Center, National Institute of General Medical Sciences, National Institute of Diabetes and Digestive and Kidney Diseases, and Office of AIDS Research. The content is solely the responsibility of the authors and does not necessarily represent the official views of USAID, PEPFAR, NIH, NHMRC, or other supporting agencies.

Competing interests: None declared.

\section{REFERENCES}

1. Baral S, Beyrer C, Muessig K, et al. Burden of HIV among female sex workers in low-income and middle-income countries: a systematic review and meta-analysis. Lancet Infect Dis. 2012;12(7):538-549. CrossRef. Medline

2. Rucinski K, Schwartz $S$, Koanda $S$, et al. High HIV prevalence and low ART coverage among AGYW who sell sex: a pooled analysis. Conference on Retroviruses and Opportunistic Infections; March 47, 2019; Seattle, WA

3. MacQueen KM, Johnson L, Alleman P, Akumatey B, Lawoyin T, Nyiama T. Pregnancy prevention practices among women with multiple partners in an HIV prevention trial. J Acquir Immune Defic Syndr. 2007;46(1):32-38. CrossRef. Medline

4. Ampt FH, Willenberg L, Agius PA, Chersich M, Luchters S, Lim MSC Incidence of unintended pregnancy among female sex workers in low-income and middle-income countries: a systematic review and meta-analysis. BMJ Open. 2018;8(9):e021779. CrossRef. Medline

5. Ippoliti NB, Nanda G, Wilcher R. Meeting the reproductive health needs of female key populations affected by HIV in low- and middleincome countries: a review of the evidence. Stud Fam Plann. 2017;48(2):121-151. CrossRef. Medline

6. Department of Reproductive Health and Research, World Health Organization (WHO). Unsafe abortion: global and regional estimates of the incidence of unsafe abortion and associated mortality in 2008. 6th ed. Geneva: WHO; 2008. https://www. who.int/reproductivehealth/publications/unsafe_abortion/ 9789241501118/en/. Accessed April 3, 2019.

7. Say L, Chou D, Gemmill A, et al. Global causes of maternal death: a WHO systematic analysis. Lancet Glob Health. 2014;2(6):e323e333. CrossRef. Medline

8. Grimes DA, Benson J, Singh S, et al. Unsafe abortion: the preventable pandemic. Lancet. 2006;368(9550):1908-1919. CrossRef. Medline

9. Beckham SW, Shembilu CR, Winch PJ, Beyrer C, Kerrigan DL. 'If you have children, you have responsibilities': motherhood, sex work and HIV in southern Tanzania. Cult Health Sex. 2015;17(2):165-179. CrossRef. Medline

10. Papworth E, Schwartz S, Ky-Zerbo O, et al. Mothers who sell sex: a potential paradigm for integrated HIV, sexual, and reproductive health interventions among women at high risk of HIV in Burkina Faso. J Acquir Immune Defic Syndr. 2015;68(Suppl 2):S154-161. CrossRef. Medline

11. Bekker L-G, Johnson L, Cowan F, et al. Combination HIV prevention for female sex workers: what is the evidence? Lancet. 2015;385 (9962):72-87. CrossRef. Medline

12. Bowring A, Ketende S, Billong S, et al. Characterising sociostructural associations with new HIV diagnoses among female sex workers in
Cameroon. J Acquir Immune Defic Syndr. 2019;80(3):e64-e73. CrossRef. Medline

13. Grosso AL, Lei EL, Ketende SC, et al. Correlates of condom use among female sex workers in The Gambia: results of a crosssectional survey. PeerJ. 2015;3:e1076. CrossRef. Medline

14. Erickson M, Goldenberg SM, Ajok M, Muldoon KA, Muzaaya G, Shannon K. Structural determinants of dual contraceptive use among female sex workers in Gulu, northern Uganda. Int J Gynaecol Obstet. 2015;131(1):91-95. CrossRef. Medline

15. Tounkara FK, Diabate S, Guedou FA, et al. Violence, condom breakage, and HIV infection among female sex workers in Benin, West Africa. Sex Transm Dis. 2014;41 (5):312-318. CrossRef. Medline

16. Shannon K, Strathdee SA, Goldenberg SM, et al. Global epidemiology of HIV among female sex workers: influence of structural determinants. Lancet. 2015;385(9962):55-71. CrossRef. Medline

17. Deering KN, Bhattacharjee P, Bradley J, et al. Condom use within non-commercial partnerships of female sex workers in southern India. BMC Public Health. 2011;11 Suppl 6(Suppl 6):S11. CrossRef. Medline

18. Luchters S, Richter ML, Bosire W, et al. The contribution of emotional partners to sexual risk taking and violence among female sex workers in Mombasa, Kenya: a cohort study. PLoS One. 2013;8(8): e68855. CrossRef. Medline

19. Weldegebreal R, Melaku YA, Alemayehu M, Gebrehiwot TG. Unintended pregnancy among female sex workers in Mekelle City, northern Ethiopia: a cross-sectional study. BMC Public Health. 2015;15:40. CrossRef. Medline

20. Heng S, Sovannary T, Chhorvann C, Gorbach P. Characteristics, risk behaviors and factors associated with abortion among female entertainment workers in Cambodia. Reprod Health. 2015;12:82. CrossRef. Medline

21. Trussell J. Contraceptive failure in the United States. Contraception. 2011;83(5):397-404. CrossRef. Medline

22. Sanders SA, Yarber WL, Kaufman EL, Crosby RA, Graham CA, Milhausen RR. Condom use errors and problems: a global view. Sex Health. 2012;9(1):81-95. CrossRef. Medline

23. World Health Organization (WHO), United Nations Population Fund, Joint United Nations Programme on HIV/AIDS, Global Network of Sex Work Projects, The World Bank. Implementing comprehensive HIV/STI programmes with sex workers: practical approaches from collaborative intervention. Geneva: WHO; 2013 https://www.who.int/hiv/pub/sti/sex_worker_implementation/ en/.

24. Dhana A, Luchters S, Moore L, et al. Systematic review of facility based sexual and reproductive health services for female sex workers in Africa. Global Health. 2014;10:46. CrossRef. Medline

25. Schwartz S, Papworth E, Thiam-Niangoin M, et al. An urgent need for integration of family planning senvices into HIV care: the high burden of unplanned pregnancy, termination of pregnancy, and limited contraception use among female sex workers in Côte d'Ivoire. J Acquir Immune Defic Syndr. 2015;68 Suppl 2:S91-S98. CrossRef. Medline

26. Lafort Y, Greener R, Roy A, et al. Sexual and reproductive health services utilization by female sex workers is context-specific: results from a cross-sectional survey in India, Kenya, Mozambique and South Africa. Reprod Health. 2017;14(1):13. CrossRef. Medline

27. Surie $D$, Yuhas $K$, Wilson $K$, et al. Association between non-barrier modern contraceptive use and condomless sex among HIV-positive female sex workers in Mombasa, Kenya: a prospective cohort analysis. PLoS One. 2017;12(11):e0187444. CrossRef. Medline

28. Luchters S, Bosire W, Feng A, et al. "A Baby Was an Added Burden": Predictors and Consequences of Unintended Pregnancies for Female 
Sex Workers in Mombasa, Kenya: A Mixed-Methods Study. PLoS One. 2016;1 1(9):e0162871. CrossRef. Medline

29. Chanda MM, Ortblad KF, Mwale M, et al. Contraceptive use and unplanned pregnancy among female sex workers in Zambia. Contraception. 2017;96(3):196-202. CrossRef. Medline

30. Ochako R, Okal J, Kimetu S, Askew I, Temmerman M. Female sex workers experiences of using contraceptive methods: a qualitative study in Kenya. BMC Womens Health. 2018;18(1):105. CrossRef. Medline

31. Tolley E, Loza S, Kafafi L, Cummings $S$. The impact of menstrual side effects on contraceptive discontinuation: findings from a longitudinal study in Cairo, Egypt. Int Fam Plan Perspect. 2005;31(1):15-23. CrossRef. Medline

32. Ampt FH, Lim MSC, Agius PA, et al. Use of long-acting reversible contraception in a cluster-random sample of female sex workers in Kenya. Int J Gynaecol Obstet. 2019;146(2):184-191. CrossRef. Medline

33. Morse J, Chipato T, Blanchard K, et al. Provision of long-acting reversible contraception in HIV-prevalent countries: results from nationally representative surveys in southern Africa. BJOG. 2013;120 (11):1386-1394. CrossRef. Medline

34. Ajong $A B$, Niotang $P N$, Kenfack $B$, et al. Contraceptive method mix and preference: $A$ focus on long acting reversible contraception in urban Cameroon. PLoS ONE. 2018;13(8):e0202967. CrossRef. Medline

35. Yangsi TT, Florent FY, Ngole ME, Nelson F. Modern contraceptive choice among patients seen at the "Cameroon National Planning Association for Family Welfare" Clinic Yaoundé. Clin Med Insights Reprod Health. 2017;11:11795581 17713016. CrossRef. Medline

36. Family Planning 2020. Cameroon FP2020 Core Indicator Summary Sheet: 2018-2019 Annual Progress Report. 2019. http://www. familyplanning2020.org/sites/default/files/Data-Hub/2019Cl/ Cameroon_2019_Cl_Handout.pdf. Accessed 2021, Jan 31 .

37. Bain LE, Kongnyuy EJ. Eliminating the high abortion related complications and deaths in Cameroon: the restrictive legal atmosphere on abortions is no acceptable excuse. BMC Womens Health. 2018;18 (1):71. CrossRef. Medline

38. Hollander D. Although abortion is highly restricted in Cameroon, it is not uncommon among young urban women. Int Fam Plan Perspect. 2003;29(1):49-50. CrossRef

39. Bongfen MC, Abanem EEB. Abortion practices among women in Buea: a socio-legal investigation. Pan Afr Med J. 2019;32:146. CrossRef. Medline

40. Mosoko JJ, Delvaux T, Glynn JR, Zekeng L, Macauley I, Buve A Induced abortion among women attending antenatal clinics in Yaounde, Cameroon. East Afr Med J. 2004;81(2):71-77. CrossRef. Medline

41. Tebeu PM, Halle-Ekane G, Da ltambi M, Enow Mbu R, Mawamba Y, Fomulu JN. Maternal mortality in Cameroon: a university teaching hospital report. Pan Afr Med J. 2015;21:16. CrossRef. Medline

42. Kamga DVT, Nana PN, Fouelifack FY, Fouedjio JH. Role of abortion and ectopic pregnancies in maternal mortality rate at 3 university hospitals in Yaounde [in French]. Pan Afr Med J. 2017;27:248. CrossRef. Medline

43. Nkwabong E, Mbu RE, Fomulu JN. How risky are second trimester clandestine abortions in Cameroon: a retrospective descriptive study. BMC Womens Health. 2014;14:108. CrossRef. Medline

44. Tumasang F, Leke RJ, Aguh V. Expanding the use of manual vacuum aspiration for incomplete abortion in selected health institutions in Yaounde, Cameroon. Int J Gynaecol Obstet. 2014;126 Suppl 1: S28-30. CrossRef. Medline

45. Ministry of Health Cameroon, Centers for Disease Control and Prevention (CDC), ICAP at Columbia University. Cameroon Population-based HIV Impact Assessment (CAMPHIA) 2017
Summary Sheet: Preliminary Findings. 2018. https://phia.icap. columbia.edu/countries/cameroon/. Published July. Accessed Aug $27,2018$.

46. Decker MR, Lyons C, Billong SC, et al. Gender-based violence against female sex workers in Cameroon: prevalence and associations with sexual HIV risk and access to health services and justice. Sex Transm Infect. 2016;92(8):599-604. CrossRef. Medline

47. Lim S, Peitzmeier S, Cange $C$, et al. Violence against female sex workers in Cameroon: accounts of violence, harm reduction, and potential solutions. J Acquir Immune Defic Syndr. 2015;68(Suppl 2): S241-247. CrossRef. Medline

48. Abelson A, Lyons $C$, Decker M, et al. Lifetime experiences of genderbased violence, depression and condom use among female sex workers in Cameroon. Int J Soc Psychiatry. 2019;65(6):445-457. CrossRef. Medline

49. Billong SC, Nguefack-Tsague G, Fokam J, et al. Mapping and size estimates of female sex workers in Cameroon: toward informed policy for design and implementation in the national HIV program. PLoS One. 2019;14(2):e0212315. CrossRef. Medline

50. Bowring AL, Ketende $S$, Rao A, et al. Characterizing unmet HIV prevention and treatment needs among young female sex workers and men who have sex with men in Cameroon: a cross-sectional analysis. Lancet Child Adolesc Health. 2019;3(7):482-491. CrossRef.

51. Santelli J, Rochat R, Hatfield-Timajchy K, et al. The measurement and meaning of unintended pregnancy. Perspect Sex Reprod Health. 2003;35(2):94-101. CrossRef. Medline

52. Zou G. A modified poisson regression approach to prospective studies with binary data. Am J Epidemiol. 2004;159(7):702-706. CrossRef. Medline

53. Barros AJD, Hirakata VN. Alternatives for logistic regression in cross-sectional studies: an empirical comparison of models that directly estimate the prevalence ratio. BMC Med Res Methodol. 2003;3:21. CrossRef. Medline

54. Starrs AM, Ezeh AC, Barker G, et al. Accelerate progress-sexual and reproductive health and rights for all: report of the GuttmacherLancet Commission. Lancet. 2018;391(10140):2642-2692. CrossRef. Medline

55. Yam EA, Mnisi Z, Mabuza X, et al. Use of dual protection among female sex workers in Swaziland. Int Perspect Sex Reprod health. 2013;39(2):69-78. CrossRef. Medline

56. Footman K, Keenan K, Reiss K, Reichwein B, Biswas P, Church K Medical abortion provision by pharmacies and drug sellers in lowand middle-income countries: a systematic review. Stud Fam Plann. 2018;49(1):57-70. CrossRef. Medline

57. Sherwood JA, Grosso A, Decker MR, et al. Sexual violence against female sex workers in The Gambia: a cross-sectional examination of the associations between victimization and reproductive, sexual and mental health. BMC Public Health. 2015;15:270. CrossRef. Medline

58. Dunkle KL, Decker MR. Gender-based violence and HIV: reviewing the evidence for links and causal pathways in the general population and high-risk groups. Am J Reprod Immunol. 2013;69 Suppl 1:2026. CrossRef. Medline

59. Leddy AM, Underwood C, Decker MR, et al. Adapting the risk environment framework to understand substance use, gender-based violence, and HIV risk behaviors among female sex workers in Tanzania. AIDS Behav. 2018;22(10):3296-3306. CrossRef. Medline

60. Wang T, Liu Y, Li Z, et al. Prevalence of intimate partner violence (IPV) during pregnancy in China: a systematic review and meta-analysis. PLoS ONE. 2017;12(10):e0175108. CrossRef. Medline

61. Kerrigan D, Kennedy CE, Morgan-Thomas R, et al. A community empowerment approach to the HIV response among sex workers: effectiveness, challenges, and considerations for implementation and scale-up. Lancet. 2015;385(9963):172-185. CrossRef. Medline 
62. Dockalova B, Lau K, Barclay H, Marshall A. Sustainable Development Goals and Family Planning 2020. 2016. hitps:// www.ippf.org/sites/default/files/2016-11/SDG\%20and\% 20FP2020.pdf

63. Adedini SA, Omisakin OA, Somefun OD. Trends, patterns and determinants of long-acting reversible methods of contraception among women in sub-Saharan Africa. PLoS ONE. 2019;14(6): e0217574. CrossRef. Medline

64. Welty TK, Bulterys M, Welty ER, et al. Integrating prevention of mother-to-child HIV transmission into routine antenatal care: the key to program expansion in Cameroon. J Acquir Immune Defic Syndr. 2005;40(4):486-493. CrossRef. Medline

65. Scorgie F, Chersich MF, Ntaganira I, Gerbase A, Lule F, Lo YR. Socio-demographic characteristics and behavioral risk factors of $\mathrm{fe}$ male sex workers in sub-saharan Africa: a systematic review. AIDS Behav. 2012;16(4):920-933. CrossRef. Medline

66. Bowring AL, Ampt FH, Schwartz S, et al. HIV pre-exposure prophylaxis for female sex workers: ensuring women's family planning needs are not left behind. J Int AIDS Soc. 2020;23(2):e25442. CrossRef. Medline

67. Quaife $M$, Vickerman $P$, Manian S, et al. The effect of HIV prevention products on incentives to supply condomless commercial sex among female sex workers in South Africa. Health Econ. 2018;27 (10):1550-1566. CrossRef. Medline

68. World Health Organization (WHO). Medical Eligibility Criteria for Contraceptive Use, 5th ed. Geneva: WHO; 2015.

69. CARE USA. Key population-led health services: achieving and sustaining HIV epidemic control in Cameroon. 2019. https://www. care.org/work/health/sexual-and-reproductive-health-and-rights/ where-we-work/west-africa/champ. Accessed 26 June 2019.

70. Kerrigan D, Mbwambo J, Likindikoki S, et al. Project Shikamana: community empowerment-based combination HIV prevention significantly impacts HIV incidence and care continuum outcomes among female sex workers in Iringa, Tanzania. J Acquir Immune Defic Syndr. 2019;82(2):141-148. CrossRef. Medline

71. Mark KE, Meinzen-Derr J, Stephenson R, et al. Contraception among HIV concordant and discordant couples in Zambia: a randomized controlled trial. J Women's Health (Larchmt). 2007; 16(8):12001210. CrossRef. Medline

72. Lafort $Y$, Lessitala F, Candrinho B, et al. Barriers to HIV and sexual and reproductive health care for female sex workers in Tete, Mozambique: results from a cross-sectional survey and focus group discussions. BMC Public Health. 2016;16:608. CrossRef. Medline

73. Corneli A, Lemons A, Otieno-Masaba R, et al. Contraceptive service delivery in Kenya: A qualitative study to identify barriers and preferences among female sex workers and health care providers. Contraception. 2016;94(1):34-39. CrossRef. Medline

74. Grossman D, Onono M, Newmann SJ, et al. Integration of family planning services into HIV care and treatment in Kenya: a clusterrandomized trial. AIDS. 2013;27 Suppl 1:S77-S85. CrossRef. Medline

75. Dulli L, Field S, Masaba R, Ndiritu J. Addressing broader reproductive health needs of female sex workers through integrated family
planning/HIV prevention services: a non-randomized trial of a health-services intervention designed to improve uptake of family planning services in Kenya. PLoS One. 2019;14(7):e0219813. CrossRef. Medline

76. Ross J, Stover J. Use of modern contraception increases when more methods become available: analysis of evidence from 1982-2009. Glob Health Sci Pract. 2013;1(2):203-212. CrossRef. Medline

77. Awungafac G, Delvaux T, Vuylsteke B. Systematic review of sex work interventions in sub-Saharan Africa: examining combination prevention approaches. Trop Med Int Health. 2017;22(8):971-993. CrossRef. Medline

78. Benova L, Cleland J, Daniele MAS, Ali M. Expanding method choice in Africa with long-acting methods: IUDs, implants or both? Int Perspect Sex Reprod Health. 2017;43(4):183-191. CrossRef. Medline

79. Charyeva Z, Oguntunde O, Orobaton N, et al. Task Shifting Provision of Contraceptive Implants to Community Health Extension Workers: Results of Operations Research in Northern Nigeria. Glob Health Sci Pract. 2015;3(3):382-394. CrossRef. Medline

80. Baumgartner JN, Green M, Weaver MA, et al. Integrating family planning services into HIV care and treatment clinics in Tanzania: evaluation of a facilitated referral model. Health Policy Plan. 2014;29(5):570-579. CrossRef. Medline

81. Haberlen SA, Narasimhan M, Beres LK, Kennedy CE. Integration of family planning services into HIV care and treatment services: a systematic review. Stud Fam Plann. 2017;48(2):153-177. CrossRef. Medline

82. World Health Organization, International Planned Parenthood Federation, Joint United Nations Programme on HIV/AIDS, United Nations Population Fund, University of California San Francisco. Sexual and Reproductive Health and HIV Linkages: Evidence Review and Recommendations. 2009. https://www.who.int/ reproductivehealth/publications/linkages/hiv_2009/en/. Published September.

83. Schwartz SR, Baral S. Fertility-related research needs among women at the margins. Reprod Health Matters. 2015;23(45):30-46. CrossRef. Medline

84. Twahima Rwema JO, Baral S, Ketende S, et al. Evaluating the vertical HIV transmission risks among South African female sex workers; have we forgotten PMTCT in their HIV programming? BMC Public Health. 2019;19(Suppl 1):605. CrossRef. Medline

85. Nyblade L, Reddy A, Mbote D, et al. The relationship between health worker stigma and uptake of HIV counseling and testing and utilization of non-HIV health services: the experience of male and female sex workers in Kenya. AIDS Care. 2017;29(1 1):1364-1372. CrossRef. Medline

86. Scorgie F, Nakato D, Harper E, et al. 'We are despised in the hospitals': sex workers' experiences of accessing health care in four African countries. Cult Health Sex. 2013;15(4):450-465. CrossRef. Medline

87. Beckham SW, Shembilu CR, Brahmbhatt $H$, Winch PJ, Beyrer C, Kerrigan DL. Female sex workers' experiences with intended pregnancy and antenatal care services in southern Tanzania. Stud Fam Plann. 2015;46(1):55-71. CrossRef. Medline

\section{En français:}

Besoins non satisfaits en planning familial et cas de grossesses non désirées chez les travailleuses du sexe en zone urbaine au Cameroun: Résultats d'une étude nationale transversale

Les travailleuses du sexe (TS) au Cameroun ont des besoins insatisfaits en contraception efficace, et les cas de grossesses non désirées et d'interruptions de grossesse sont fréquents. La réduction des barrières à l'accès aux services de qualité de planning familial volontaire dans les services communautaires dédiés aux TS est une stratégie majeure dans la promotion des soins centrés sur le client, du choix éclairé, de la réduction des grossesses non désirées et l'amélioration de la qualité de vie des TS.

RÉSUMÉ 
Contexte: Les besoins en contraception des travailleuses du sexe (TS) au Cameroun sont généralement non satisfaits, ce qui représente un risque élevé de grossesses non désirées. Les grossesses non désirées entrainent une série de résultats et, en raison de restrictions légales, les FSW recherchent souvent des avortements dangereux. Hormis la charge élevée du VIH, très peu d'informations relatives à la vie sexuelle et reproductive des TS au Cameroun sont connues.

Méthodes: De décembre 2015 à octobre 2016, des TS âgées de plus de 18 ans ont été recrutées dans 5 villes du Cameroun à l'aide d'un échantillonnage fondé sur les répondants. Des données transversales ont été recueillies à l'aide d'un questionnaire comportemental et du dépistage biologique du $\mathrm{VIH} /$ syphilis. Une approche modifiée et fiable de la régression de Poisson a été utilisée pour parvenir à une approximation des taux de prévalence ajustés (TPa) des IVG et l'utilisation en cours de contraceptifs non barrières efficaces.

Résultats: Des 2255 TS (âge médian, 28 ans), 57,6\% ont rapporté une grossesse non désirée et $40 \%$ une IVG antérieure. Au cours de l'analyse multivariables, les antécédents d'IVG ont été associés à l'utilisation de méthodes contraceptives non barrières (TPa=1,23,95\% intervalle de confiance $[I C]=1,07,1,42)$; l'utilisation systématique de la contraception d'urgence ( $T P a=1,34,95 \%, I C=1.17,1,55)$; $>60$ clients au cours du mois précédent ( $T P a=1,29,95 \%$ IC $=1,07,1,54)$ contre $£ 30$; l'utilisation non systématique du préservatif avec les clients (TPa=1,17, 95\% IC $=1,00$, 1,37); la violence physique ( $T P a=1,24,95 \%$ IC $=1,09,1,42)$; et l'âge avancé. La majorité des femmes $(76,5 \%)$ utilise le préservatif masculin comme contraception, mais seules $33,2 \%$ ont déclaré une utilisation constante du préservatif avec tous les partenaires. Au total, $26,4 \%$ des femmes ont déclaré qu'elles utilisent actuellement une méthode contraceptive non barrières, et $6,2 \%$ ont déclaré qu'elles utilisent une méthode contraceptive à longue durée d'action. Les antécédents d'IVG (TPa=1,41,95\% IC = 1, 16, 1,72) et l'utilisation systématique de la contraception d'urgence (TPa=2,70,95\% IC =2,23, 3,26) ont été associés à l'utilisation élevée de méthodes contraceptives dites non barrières. L'obtention récente d'informations sur le VIH (TPa=0,72,95\% IC=0,59, 0,89 ) et l'adhésion à une organisation à base communautaire pour les $\mathrm{TS}(\mathrm{TPa}=0,73,95 \% \mathrm{IC}=0,57,0,92)$ ont ééé associées à la faible utilisation des méthodes contraceptives non barrières.

Conclusion: Les cas de grossesse non désirées et d'VG sont fréquents chez les TS au Cameroun. Au vu de la faible utilisation des méthodes contraceptives non barrières et la non utilisation systématique du préservatif, les TS présentent un risque de contracter des grossesses non désirées de manière répétée. Une meilleure intégration des services de planning familial volontaire axés sur le client au sein des services communautaires du VIH permettraient de mieux appuyer la santé sexuelle et reproductive et les droits de l'homme des TS conformément à la Déclaration des droits de l'homme des Nations Unies.

\section{Peer Reviewed}

Received: September 24, 2019; Accepted: February 28, 2020

Cite this article as: Bowring AL, Schwartz S, Lyons $\mathrm{C}$, et al. Unmet need for family planning and experience of unintended pregnancy among female sex workers in urban Cameroon: results from a national cross-sectional study. Glob Health Sci Pract. 2020;8(1):82-99. https://doi.org/10.9745/GHSPD-19-00330

(c) Bowring et al. This is an open-access article distributed under the terms of the Creative Commons Aftribution 4.0 International License (CC BY 4.0), which permits unrestricted use, distribution, and reproduction in any medium, provided the original author and source are properly cited. To view a copy of the license, visit http:// creativecommons.org/licenses/by/4.0/. When linking to this article, please use the following permanent link: https:// doi.org/10.9745/GHSP-D-19-00330 